\title{
Estudio pedagógico sobre prácticas orientadas a la formación de futuros docentes
}

\section{Pedagogical study on practices aimed at training future teachers}

\author{
Mahmut Oğuz Kutlu ${ }^{1}$, Peruza Zharylgassova ${ }^{2}$, Pınar Akman ${ }^{3 a}$ \\ Çukurova University, Adana, Turkey ${ }^{13}$ \\ Yessenov Caspian State University, Aktau, Kazakhstan ${ }^{2}$ \\ D ORCID ID: https://orcid.org/0000-0002-6539-2354 ${ }^{1}$ \\ ORCID ID: https://orcid.org/0000-0001-7606-712X ${ }^{2}$ \\ ORCID ID: https://orcid.org/0000-0002-5243-9918 3
}

Recibido: 29 de diciembre de 2020

Aceptado: 28 de junio de 2021

\begin{abstract}
The aim of this research is to investigate an academic involvement of instructor preparing on the subject of proficient instruction, a curricular unit which is portion of the degrees on instruction instructed at National college (Kazakhstan). The design of this research is the case study design, which is one of the qualitative research designs. The participants of the research consisted of fifty Kazakh undergrad learners Aktau city. In the research, "Semi-Structured Interview Form" and "Portfolio Assessment" were used as the data collection instruments. In this research, the data was analyzed using the "Descriptive Analysis" technique, one of the qualitative data analysis methods. Concurring to the investigation comes about, the recognizing of individual alters at imperative levels for the securing of information and competences, as well as an organizing of the idea of instructing from the basic thought of its inherently moral and intersubjective nature was found.
\end{abstract}

Keywords: Teacher development, pedagogical training, educational preparing, deontological training, practical training, portfolio.

\section{Resumen}

El objetivo de esta investigación es analizar la participación académica del instructor que se prepara en el tema de instrucción competente, una unidad curricular que forma parte de las titulaciones sobre instrucción impartidas en el Colegio Nacional (Kazajstán). El diseño de esta investigación es el modelo del estudio de caso, que es uno de los diseños de investigación cualitativa. Los participantes de la investigación consistieron en cincuenta estudiantes de pregrado kazajos de la ciudad de Aktau (Kazajistán). En la investigación, el "Formulario de 
entrevista semiestructurado" y la "Evaluación de la cartera" se utilizaron como instrumentos de recopilación de datos. En esta investigación, los datos se analizaron mediante la técnica de "Análisis descriptivo", que es uno de los métodos de análisis de datos cualitativos. Coincidiendo con la investigación, se encontró el reconocimiento de las alteraciones individuales a niveles imperativos para la obtención de información y competencias, así como una organización de la idea de instruir a partir del pensamiento básico de su naturaleza inherentemente moral e intersubjetiva.

Palabras clave: Desarrollo docente, formación pedagógica, preparación educativa, formación deontológica, formación práctica, portafolio.

\section{Introduction}

The phenomenon of education has three basic elements that constantly interact with each other. These three basic elements are called student, teacher and program. The effectiveness and efficiency of an education system depends on the progress of these three elements in harmony towards a specific goal (Üstüner, 2004). Any failure, weakness, inefficiency or malfunctioning of any of these elements will reduce the efficiency of an entire system. It cannot be said that any of these items is more important than the other. However, the teacher element of these requires careful attention (Avc1, 2014). Because education faculties do not have a control power as institutions that train teachers over students, which are the input of the education system. The element we have the most control over in ensuring the effective functioning of our education system is the "teacher training" process. The teacher provides the most influence over the other two elements (Kutlu, 2020).

Teacher qualifications are important in all educational systems because student achievement is heavily dependent on teacher quality. The progress of society is directly related to the quality of education provided in schools, that requires increasing the qualifications of teachers as people who will provide education. It is a fact accepted by the researchers that the relationship between teaching quality and teacher quality affects society significantly (Gürlen \& Demirel, 2010; Harris \& Sass, 2011). According to the researches, teacher qualifications have a greater impact on student performance than curriculum, instructional methods, materials, equipment, school buildings, and parents, because teacher education is the most important factor in determining teacher quality (Ekinci, 2020). Pre-service education, induction period education, and in-service education are the three stages of teacher education. These three stages are experienced by all teachers. There is a strong relationship between the quality of their development and the quality of support they receive at each stage. As a result, it is critical for 
policymakers working to improve education systems to develop policies that promote teacher professional development (Erdem, 2013).

In recent years, there has been renewed interest in addressing this shortcoming by focusing more on the development of teacher practices, which consists broadly of enacting the work of the profession and may include a professional learning community organized around a specific instructional system (Epstein, 2018). While there are competing and disparate conceptualizations of teacher practices, such enactments necessitate "their attention beyond the cognitive demands of teaching, which have dominated the field for the past 20 years, to an expanded view of teaching that focuses on teaching as a practice that encompasses deontology, and affect" (Hurlbut \& Krutka, 2020, p 34). Such teacher practice entails more than just "accumulating strategies and activities" and necessitates teachers becoming serious learners in and around their practice. This trend toward developing pedagogies of enactment through teacher preparation programs is known as Pedagogical Training.

Within the conditions of energetic changes in Kazakhstan society and the modernization of the instruction framework as an asset for these changes, the move to a multi-level higher instruction, the issue of the quality of proficient preparing of instructors is of specific significance (Alarcao, 2003). It characterizes the prospects for the advancement of instruction as a necessarily portion of the culture of humankind and society as an entirety. Effective proficient exercises of a present educator require a tall level of competence, counting in things of proficient behavior. From this point of see, the deontological preparing of future instructors, which alludes to the deliberate and controlled handle of planning the subject for the usage of standardizing behavior in proficient exercises, gets to be exceedingly pertinent (Quezada \& Alexandrowicz, 2019).

Pedagogical Training is not a separated region of human information. It is interrelated with the sciences that ponder a human being from different points of view. Educational preparing and reasoning interrelation is followed in assurance of methodological approaches in shaping of deontological status of future educator, in designs of improvement of one or another society into different social-economic arrangements (Stoyanov, et al., 2014). Such parts of reasoning as rationalizations, hypothesis of information advance the advancement of teacher's research thought because it is one of the files of deontological status. Educational Preparing centers on examining instructor capabilities. Deontological readiness is considered to be one of the desired instructor capabilities (Mykolaiovych, et al., 2018).

There are a few elucidations of the term "deontological preparedness." The essential component of the structure of teacher's identity is the professional - educational introduction 
shaping "the skeleton circular which the fundamental properties of teacher's identity arrange" (Kertayeva and Meirkulova, 2015, p. 180) consider that it is tricky to isolated genuine educational qualities from other changed highlights of a teacher's identity, which impact his proficient action. Being a blend of shifted capacities, qualities of intellect, and sentiments, these qualities appear up, are shaped and created within the common structure of the qualities, relations and activities of the teacher's identity.

In this article, we display an academic involvement on the individual, social and proficient improvement of educator understudies given within the curricular unit of Proficient Preparing. The article presents the result of the primary preparing encounter on the subject, indicating the structure of that curricular unit and the assessment performed by the understudies with respect to their discernments on teaching impacts, once the instructing period ceased. According to Gilette (2011)The most thought supporting our instructive work is the acknowledgment, as a beginning point, that Education suggests an axiological introduction which structures the entire hone. Instruction is not impartial and the purposeful to display it as such carries a philosophy seeking after particular goals to be come to by their dissimulation.

The instructing calling postures especially important moral and deontological requests within the individual and proficient improvement of its operators. Subsequently, the identity of the educator ought to be the coordinate question of the preparing hone to a significant degree, both in Benefit Preparing (Kertayeva \& Meirkulova, 2015).

\section{Definitions}

\section{Deontology}

According to Hooker (2012), the word deontology derives from the Greek words for duty (deon) and science (or study) of (logos). In contemporary moral philosophy, deontology is one of those kinds of normative theories regarding which choices are morally required, forbidden, or permitted. In other words, deontology falls within the domain of moral theories that guide and assess our choices of what we ought to do (deontic theories), in contrast to those that guide and assess what kind of person we are and should be theories (Kertayeva \& Meirkulova, 2015).

\section{Portfolio}

A portfolio may be a folder containing a student's best pieces and the student's evaluation of the strengths and weaknesses of the pieces (Polat \& Köse, 2013). It may also contain one or more works-in-progress that illustrate the creation of a product, such as an essay, 
evolving through various stages of conception, drafting, and revision (Qvortrup \& Keiding, 2015).

\section{Methodology}

\section{Type of research}

The design of this research is the case study design, which is one of the qualitative research designs. The case study is set up to understand a system created by a particular individual, class, or institution, usually in its natural environment (Karasar, 2017). Qualitative situation studies, factors related to a situation are investigated with a holistic approach. and how they affect the relevant situation and how they are affected by the situation are focused on. According to Yıldırım \& Şimşek (2018), the events and facts studied in social sciences researches are examined within their own environment and the researcher tries to explain and interpret these events and facts in detail and in depth.

\section{Participants}

The participants of the research consisted of fifty Kazakh undergrad learners in Aktau city. Most of the learners (66\%) was youngsters and the rest of them (34\%) was seniors. In terms of the gender, the learners did not adjust with 48 females (95\%), 2 guys (5\%), and their age extended from 16 to 20 .

\section{Data collection instruments}

In the research, "Semi-Structured Interview Form" and, "Portfolio Assessment" were used as the data collection instruments. According to Yıldırım \& Şimşek (2018), the interview approach includes a list of questions or topics to be examined during the observation. This method is used to collect the same type of information from different people in order to address similar issues. A portfolio assessment is a collection of student works that are associated with standards you are required to learn. This collection of work is often gathered over a long period of time to reflect what you have been taught as well as what you have learned.

The use of portfolios for large-scale assessment and accountability purposes poses vexing measurement challenges. Portfolios typically require complex production and writing, tasks (Rubenson, 2011). Generalizability and comparability can also be an issue in portfolio assessment, as portfolio tasks are unique and can vary in topic and difficulty from one classroom to the next. To the extent student choice is involved, contents may even be different from one 
student to the next. Conditions of, and opportunities for, performance thus vary from one student to another (Polat \& Köse, 2013). So, during the research we came up with questions:

1. What is the students' recognition and affirmation of their individual alter?

2. What is the meaning disclosure and how is it seen and recognized by the students?

\section{Analysis of data}

In this research, the data was analyzed using the "Descriptive Analysis" technique, one of the qualitative data analysis methods. According to Yıldırım and Şimşek (2018), the data obtained in the descriptive analysis approach is summarized and interpreted according to previously determined themes. In this approach, direct quotations are frequently used to reflect the views of the individuals interviewed or observed. In this type of analysis, the aim is to present the obtained findings to the reader in an organized and interpreted form (Lawless \& Heymann, 2010).

\section{Results}

Amid one semester, with 45 hours (15 sessions/3 hours each) of classroom-based preparing and an estimation of an additional 45 hours of person work, the curricular unit of Proficient Preparing is pointed at accomplishing the taking after goals. The primary one is to permit the understudies the opportunity to reflect on their individual involvement as understudies. In this way, the curricular unit is assumed to energize a prepare of individual and professional growth. In arrange to attain this, the perfect circumstances would be to turn the curricular unit into a scholarly year module, but the display lawful definition does not and will not permit it.

The understudies are moreover assumed to assess their preparing as instructor learners. Having this curricular unit on the final year of their preparing gives the understudies an opportunity of looking back into their past learning involvement and to reflect on their desires and ventures, questions and certainties, capacities and inspirations, trusts and fears. By making these circumstances, understudies are moreover given space and time for sharing encounters. This way, the visit individual and proficient issues that are frequently raised within the starting of their careers may be maintained a strategic distance from or at slightest minimized. The reality that our preparing courses set the understudies in proficient settings from the minute 
they select is especially imperative to this activity (Callejo, 2001). The outcomes for the processing of portfolios are shown in Table 1:

Table 1

The Outcomes for The Processing of Portfolios

The outcome 1 They gotten to be more cognizant of their calling and its conditions, which per se may be a positive point.

The outcome 2 Another one is to recognize the significance given to individual and social advancement by the Instructive standards, both in what concerns instructors and understudies, as we have already alluded.

The outcome 3 It is additionally critical to clarify this and to gotten to be mindful of their ventures as an individual, a citizen and a proficient.

The outcome 4 The improvement of competences of interpersonal relationship completely different settings is additionally an objective to be come to.

The non-formal instruction approach and its techniques of advancing values and individual advancement are given a pertinent put in this curricular unit. The other educational errand, which must be completed exclusively, comprises of an intelligent Portfolio, in which their involvement with the understudies and instructor preparing, seen from the deontological viewpoint, is the major concern (Polat \& Köse, 2013). Its structure is shown in Table 2.

Table 2

The curricular units of portfolios

\section{Units Subjects}

Unit 1 Characterization of my whole professional and academic training

Unit 2 Expectations toward my training - What has been achieved or not, difficulties found etc.

Unit 3 My personal and social development in Higher Education - values I have brought, achieved

Unit 4 My experience as a primary and secondary student experience, values etc.

Unit 5 My projects as a person, a citizen and a professional 
Unit 6 Essays produced in the curricular unit of Professional Training

Unit 7 My path in Professional Training

It appears all the log units gotten within the investigation prepare. The taking after viewpoints of the examination can be highlighted. In a brief outline of the complete fabric created inside the setting of the Portfolios, able to securely state that the preparing accomplished exceptionally palatable comes about, concurring to the self-perception of the learners (Polat \& Köse, 2013). The elaboration of the Portfolio pointed at assessing the students' execution within the curricular unit. It was created all along the semester beneath the supervision of the speaker. The processing of portfolios is shown in Table 3.

Table 3

The processing of portfolios

The

The Steps for the Processing of Portfolios

Processing

The step 1 The supervision was done in the classes, in which some time was devoted to reply anything questions the understudies displayed, and amid the coaching time.

The step 2 The understudies were told of the extra point of the Portfolio, that of making a difference assessing the curricular unit and progressing its course in time.

The step 3 A main perspective of the understudies' discourse within the Portfolio must do with the reality that the delivered writings had to display an impressive review of improvement and reflection.

The step 4 No straightforward writings or answers were planning. On the opposite, complex and intelligent writings were created, permitting a significant run of individual thought, and the ensuing requesting elucidation performed by the agent.

The views of the understudies in portfolios processing are shown in Table 4. 


\section{Table 4}

The views of the understudies in portfolios processing

\section{The views of the understudies in portfolios processing}

Confronting with an emphatically shocking encounter.

Proposing expanding the curricular unit to a scholastic year, rather than an insignificant semester

Recognizing the importance of time within the handle through the preparing performed f

This can be an involvement we have had for numerous a long time within the outline of the curricular unit of Individual and Social Advancement, too instructed in our institution, and which runs through the course of a scholastic year. For the minute, Proficient Preparing cannot experience this alter, and the curricular adjustment happened beneath the Bologna process does not permit it. At a closer see, and taking the fabric assembled the substance examination categories into consideration, the taking after conclusions may be drawn (Gilette, 2011).

\section{Discussion}

Based on the literature review, the results of the research presented in this article are consistent to a certain extent with the data given by some researchers. The results obtained from this research and the results of some related researches in the literature were compared and related. In this research, it is suggested that the non-formal teaching approach and the techniques used in the application of this approach in the training of future teacher candidates should be developed and organized on the basis of student portfolios in order to develop values in students and to ensure value-based individual development. Similarly, Sadio (2011) presents a report of the pedagogical experiences of pre-service teachers; the necessity of including Deontology as a part of Curricular was stated based on the opinions of the students in their portfolios.

According to Reboul (2011), education is not limited to imparting knowledge, improving skills or socializing, or briefly teaching predetermined subjects. Education should take the person as a whole and develop it in all aspects. In this context, teacher candidates need to be trained not only in teaching skills but also in values education and morality, and courses 
containing these subjects should be added to the 4th grade of teacher training programs (especially for pre-school and basic education teacher candidates).

On the other hand, Ramos and Reis (2005), also emphasized that the inclusion of Deontology in teacher training programs will support the value systems, and personality development of teachers, in fact, this development has a continuity feature, so that in addition to the balance of theory and practice of professional development in pre-service teachers, the development in the affective domain would create unity. For his part, Cacius (2014) has reached that the primary source of responsibility in education is the teacher. Beyond reporting to a general set of rules and codes, the teacher's ethical responsibilities include the ability to find appropriate solutions for specific situations, to display behaviors that are consistent with the achiever's beliefs, and to live the moral values, not just declare them.

In this research, students expressed their opinions about the program in their portfolios about expections toward my training- what has been achieved or not, difficulties found, etc., and stressed that the importance of continuing the relevant units for a longer period of time, not just for a period, in the training of teachers in both Cognitive and Affective domains. Regarding this result, Marusic, Jugovic and Loncaric (2017) showed that the last year students were more conscious about the teaching profession than the first-year students, their self-efficacy was high and, they stated the importance of goal-centered, and more in-depth teaching. This situation also has showed how more effective learning and self-belief levels can develop towards the end of the teacher education process compared to students who have just started their teacher education.

In this research, it was stated that in the affective domain training of teachers, only theoretical training would not be sufficient, but also practical training should be given. It was stressed by Kazakh teacher candidates who participated in the research that this situation should also be valid for cognitive domain training. Regarding this result, the study by Grigorevna (2015) has reached that in the process of professional training, it is necessary to achieve a balance between students' theoretical knowledge and practice-based teaching. Improving the relationship between theory and practice in basic professional educational programs of teacher education will enable the future teachers to use both types of knowledge for the successful implementation of labor activity at school. In addition, Prosalova and Nikolaeva (2020) have concluded that practice-oriented approach allows students to acquire necessary professional skills and competence, to obtain experience of organizational work, the system of theoretical knowledge, ability to work in a team and to take responsibility for the decisions made. 
Finally, two matters limit the present study. First, the study is limited to prospective teachers studying at the Department of "Pedagogy and Psychology" at Yessanov Caspian State University in Aktau, Kazakhstan. Second, it is limited to the fact that only views and opinions have been obtained without using a scale or questionnaire whose reliability and validity have provided.

\section{Conclusion}

Concurring to the investigation comes about, it was noticed that individual improvements were recognized at imperative levels to secure knowledge and competencies, as well as organizing the concept of teaching its fundamentally moral and intersubjective essence from the fundamental thinking.

Based on the results of the present study, following suggestions can be made: Comparative studies should be conducted by taking the opinions of first and last year students studying in different branches in educational institutions that train teachers. The opinions and thoughts of those who continue their education and graduate and still work as teachers should be obtained and compared. Similar and different views and opinions of the students should be determined and analyzed by taking the opinions of the lecturers on the subject.

\section{References}

Alarcao, I. (2003). Reflective teachers in a reflective school. Sao Paulo: Cortez Publisher.

Avc1, A. (2014). Introduction to educational sciences. İstanbul: Türdav Publishing.

Caciuc, V. T. (2014). The role of virtue ethics in the deontological training of prospective teachers. Logos Universality Mentality Education Novelty, Section: Social Sciences, 1, 47-56. https://ideas.repec.org/a/lum/rev17s/v1y2014ip47-56.html

Callejo, J. (2001). The discussion group: introduction to a research practice. Chicago: Ariel Publisher.

Ekinci, N. (2020). A study on the experiences of beginning classroom teachers on teacher induction practices in rural areas in Turkey. Journal of Teacher Education and Educators, 9 (3), 349-382. https://dergipark.org.tr/tr/pub/jtee/issue/59104/811471

Epstein, J. L. (2018). School, family, and community partnerships: Preparing educators and improving schools. New York: Westview Press.

Erdem, A. R. (2013). Present and future of teacher training: Problems and solution suggestions. Ankara: Ani Publishing.

Gilette, C. M. (2011). Preparing proficient practitioners: Problem-based learning in athletic training education. Capella: ProQuest Dissertations Publishing. 
Grigorevna, M. N. (2015). Pedagogical maintenance of future teachers' practice-oriented training. Indian Journal of Science and Technology, 8 (10), 1-8. https://indjst.org/articles/pedagogical-maintenance-of-future-teachers-practiceoriented-training

Gürlen, E. \& Demirel, Ö. (2010). Comparative examination of teacher competencies in the European union and Turkey. Paper presented at International Symposium on Teacher Training Policies and Problems II 16 - 18 May, 2010 Ankara-Turkey.

Harris, D. N. \& Sass, T. R. (2011). Teacher training, teacher quality and student achievement. Journal of Public Economics, $95 \quad$ (7-8), 798-812. https://files.eric.ed.gov/fulltext/ED509656.pdf

Hooker, B. (2012). Developing deontology: New essays in ethical theory. New Jersey: WileyBlackwell.

Hurlbut, A. R. \& Krutka, D. G. (2020). Where do we start?: Initiating a practice-based teacher education program around high-leverage practice. Journal of Teacher Education and Educators, 9 (2), 169-199. https://dergipark.org.tr/tr/pub/jtee/issue/56618/653811

Karasar, N. (2017). Scientific research method. Ankara: Nobel Publishing.

Kertayeva, K. \& Meirkulova, A. (2015). Competence-based approach in the system of forming deontological preparedness of specialists. Berlin: Springer International Publishing.

Kutlu, M. O. (2020). Introduction to educational sciences. Ankara: Akademisyen Publishing.

Lawless, H. T. \& Heymann, H. (2010). Descriptive analysis. Berlin: Springer International Publishing.

Marusic, I., Jugovic, I. \& Loncaric, D. (2017). Approaches to learning of first- year and fifth year student teachers: are there any Differences? European Journal of Teacher Education, 40, 1,62-75. https://eric.ed.gov/?id=EJ1127135

Mykolaiovych, K. O., Mykolaivna, S. N., Vasylivna, B. V. \& Mykhailivna, P. S. (2018). Improving professional and pedagogical training of future teachers by Moodle platforms (on the example of the course "Pedagogy"). Scientific Vector of the Balkans, 1, 53-58. https://cyberleninka.ru/article/n/improving-professional-and-pedagogical-training-offuture-teachers-by-moodle-platforms-on-the-example-of-the-course-pedagogy

Polat, M. \& Köse, Y. (2013). Perceptions of primary education teachers towards the use of eportfolio as a tool of performance evaluation in schools. Journal of Computer and Educational Research, 1 59-82. https://dergipark.org.tr/tr/pub/jcer/issue/18613/196491

Prosalova, V. S. \& Nikolaeva, A. A. (2020). Implementation of practice-oriented training as the basis of university competitiveness. Advances in Economics, Business and Management Research, 128, 367-373. https://www.atlantispress.com/proceedings/iscfec-20/125936279

Quezada, R. \& Alexandrowicz, V. (2019). Developing culturally proficient teachers for duallanguage classrooms. Theory Into Practice, 58 (2), 185-193. 
https://www.tandfonline.com/doi/pdf/10.1080/00405841.2019.1569398?needAccess=t rue

Qvortrup, A. \& Keiding, T. B. (2015) Portfolio assessment: production and reduction of complexity. Assessment \& Evaluation in Higher Education, 40 (3), 407-419. https://www.tandfonline.com/doi/pdf/10.1080/02602938.2014.918087?needAccess=tr ue

Ramos, F. \& Reis, I. B. (2005). Professional deontology for future teachers. Escola Superior de Educação de Coimbra 74-81. https://scholar.google.com.tr/scholar?hl=tr\&as_sdt=0\%2C5\&as_vis=1\&q=Professiona $1+$ deontology+for+future+teachers $\& b \operatorname{bth}=$

Rubenson, K. (2011). Adult learning and education. Cambridge: Cambridge Academic Press.

Sadio, F. (2011). Professional deontology in teacher training. Report on a training experience. Publicaciones, 41, 9-31. https://dialnet.unirioja.es/descarga/articulo/3830744.pdf

Santos, J. M. F. (2008). Values and teaching ethics. An empirical study. Ibero-American Journal of Education, 47 (2), 1-14. https://rieoei.org/RIE/article/view/2368

Stoyanov, S., Sloep, P., Bie, M. D. \& Hermans, V. (2014). Teacher-training, ICT, creativity, mooc, moodle - What pedagogy? Paper presented at 6th International Conference on Education and New Learning Technologies 7-9 July, 2014, Barcelona, Spain.

Üstüner, M. (2004). Teacher training in Turkish education system from past to present and current problems. Paper presented at İnönü University January, 2004 Malatya-Turkey.

Yıldırım, A. \& Şimşek, H. (2018). Qualitative research methods in the Social Sciences. Ankara: Seçkin Publishing. 